\title{
Efficiency, merit and privilege: public administration reforms in Brazil and Turkey
}

\section{Karabekir Akkoyunlu}

Lecturer, Fundação Getúlio Vargas, Escola de Relações Internacionais, São Paulo - SP, Brazil

The Brazilian and Turkish public administrations display a mixture of patrimonial, traditional bureaucratic and managerial characteristics. This patchwork is a result of more than a century of disjointed reform attempts to address chronic institutional problems such as government inefficiency, political patronage and corruption. Based on a comparative study of the two cases using official data, reports and a review of the public administration literature, this paper analyses the historical evolution and present structures of the civil service in Brazil and Turkey. Both public administrations continue to face diverse sets of challenges today, albeit in different forms and degrees: government inefficiency comes across as a major problem in Brazil, while the deterioration of the merit principle is particularly disconcerting in Turkey. Public sector employees enjoy more limited rights and benefits in Turkey compared to Brazil, where the civil service is faced with the opposite charge of undue privilege in a highly unequal society. Finally, while corruption and political patronage remain problematic in both cases, their causes appear to be different.

Keywords: Brazil, Turkey, public administration reform 


\section{Eficiência, mérito e privilégio: reformas da administração pública no Brasil e na Turquia}

As administrações públicas brasileira e turca apresentam uma mistura de características patrimoniais, burocráticas e administrativas tradicionais; o resultado de mais de um século de tentativas desarticuladas de reforma para abordar problemas institucionais crônicos, como ineficiência do governo, patrocínio político e corrupção. Com base em um estudo comparativo dos dois casos, utilizando dados oficiais, relatórios e uma revisão da literatura da administração pública, este artigo analisa a evolução histórica e as estruturas atuais da função pública no Brasil e na Turquia. Todas as duas administrações públicas continuam enfrentando diversos conjuntos de desafios atualmente, embora de formas e graus diferentes: a ineficiência do governo aparece como um grande problema no Brasil, enquanto a deterioração do princípio do mérito é particularmente desconcertante na Turquia. Os funcionários do setor público desfrutam de direitos e benefícios mais limitados na Turquia em comparação com o Brasil, onde o serviço público enfrenta a acusação oposta de privilégio indevido em uma sociedade altamente desigual. Finalmente, embora a corrupção e o patrocínio político permaneçam problemáticos nos dois casos, suas causas parecem ser diferentes.

Palavras-chave: Brasil, Turquia, reforma da administração pública

\section{Eficiencia, mérito y privilegio: reformas de la administración pública en Brasil y Turquía}

Las administraciones públicas brasileña y turca presentan una mezcla de características patrimoniales, burocráticas y administrativas tradicionales, siendo el resultado de más de un siglo de intentos desconectados de reforma para abordar problemas institucionales crónicos como la ineficiencia del gobierno, el patrocinio político y la corrupción. Basado en un estudio comparativo de los dos casos, utilizando datos oficiales, informes y una revisión de la literatura de la administración pública en ambos países, este artículo analiza la evolución histórica y las estructuras actuales del servicio civil en Brasil y Turquía. Las dos administraciones públicas continúan enfrentando diferentes desafíos en la actualidad, aunque en diferentes formas y grados: la ineficiencia del gobierno parece ser un problema importante en Brasil, mientras que el deterioro del principio de mérito es particularmente desconcertante en Turquía. Los empleados del sector público disfrutan de derechos y beneficios más limitados en Turquía en comparación con Brasil, donde el servicio público enfrenta el cargo opuesto de privilegio indebido en una sociedad altamente desigual. Finalmente, aunque la corrupción y el patrocinio político siguen siendo problemáticos en ambos casos, sus causas parecen ser diferentes.

Palabras clave: Brasil, Turquía, reforma de la administración pública 
Introduction

Despite their obvious cultural, geographic, demographic and administrative differences, Brazil and Turkey have been compared frequently in recent years. During the 2000s, both were categorised as emerging powers, featuring popular governments overseeing sustained economic growth and ambitious foreign policies. Since 2013, the comparisons have focused more on the countries' troubles, as both Brazil and Turkey experienced political and economic crises, anti-government protests, corruption scandals, and concerns of democratic backsliding (FreEdom House, 2018). As a World Economic Forum study recently reported, "among the emerging markets seen as having great potential in the early 2000s, Brazil and Turkey have now lost much of the ground they gained before 2013" (WEF, 2018, p. 16).

Amidst narratives of fast-paced rise and decline, one slow-changing and long-term comparison that can reveal much about the two countries has gone largely unnoticed: the evolution of the civil service. From the late $19^{\text {th }}$ century onwards, governments in Brazil and Turkey have undertaken near simultaneous initiatives to reform their public administration. For much of the $20^{\text {th }}$ century both countries made periodic advances to build a modern, rational bureaucracy in the Weberian tradition. From the 1980s onwards, their paths started to diverge. Turkey made a radical transition to free market economics following its 1980 military coup, where successive centre-right governments oversaw comprehensive privatisation schemes and implemented private sector practices in the public sector. Conversely, in Brazil, the end of the military dictatorship saw the strengthening of the centralised, merit-based bureaucracy. Compared to Turkey, attempts to liberalise the public service remained more limited. The liberal reform agenda under Cardoso's administration in the mid-1990s gradually fizzled and was mostly discarded under the Workers' Party (PT) governments.

The aim of this paper is to analyse the institutional outcomes of these simultaneous yet divergent processes of change from a comparative perspective. The paper first traces the historical evolution of the Brazilian and Turkish public administrations, with an emphasis on their post-1980 trajectories. It then provides a structural comparison of the civil service in Brazil and Turkey, focusing on government efficiency and effectiveness, 
merit and professionalism, rights and benefits, demographic representation and gender balance. It concludes that the institutional paths that the two countries took since the 1980s, and the political developments of the past decade, have contributed significantly to the distinct set of challenges facing the Brazilian and Turkish public administrations today.

\section{Evolution of the Civil Service in Brazil and Turkey}

A legacy of their imperial past, civil service was long considered an elite preoccupation in Brazil and Turkey. Starting in the $19^{\text {th }}$ century, Brazilian and Ottoman reformers supplemented this traditional view with a modernist perspective, which treated civil service as the embodiment of a modern, well-functioning and rational nation-state. During the $20^{\text {th }}$ century, successive Brazilian and Turkish governments initiated periodic yet disjointed reforms aimed at institutionalising a centralised and professional public administration in pursuit of this elusive goal. This century-long evolution is marked by five distinct periods of policy development and implementation (Table 1). In two of these periods (the 1960s and 1980s) the reforms in Brazil and Turkey took place in opposite directions, while in the other three they shared similar objectives and characteristics.

\subsection{From the Turn of the Century to the $1980 \mathrm{~s}$}

Brazil and what was then the Ottoman Empire entered the $20^{\text {th }}$ century having embraced European-inspired ideas of modernisation and progress. Brazilian and Ottoman reformers of the $19^{\text {th }}$ and the early $20^{\text {th }}$ centuries saw the civil service through an imperial and positivist lens simultaneously, both as an elite preoccupation and as the institutional embodiment of a modern and rational state apparatus. Yet during the First Brazilian Republic (1889 - 1930) and the late Ottoman Empire (1879 - 1922), the lack of resources, expertise and/or political will (and in the Ottoman case, continuous warfare) meant that the discourse of progress and modernisation often fell short of translating into actual policy and the patrimonial roots of public administration remained intact. 
Table 1 | Evolution of the Civil Service in Brazil and Turkey

\begin{tabular}{|c|c|c|}
\hline & Brazil & Turkey \\
\hline $\begin{array}{l}\text { Turn of the } 20^{\text {th }} \\
\text { century }\end{array}$ & "Order and Progress" & "Union and Progress" \\
\hline Interwar Era & $\begin{array}{l}\text { "New Republic" } \\
\text { Reforms of Getúlio Vargas (1934-37) } \\
\text { Centralisation, Rationalisation, Moder- } \\
\text { nisation }\end{array}$ & $\begin{array}{l}\text { “New Republic” } \\
\text { Reforms of Kemal Atatürk (1923 } \\
\text { - 38) } \\
\text { Centralisation, Rationalisation, } \\
\text { Modernisation }\end{array}$ \\
\hline 1960s & $\begin{array}{l}\text { “Military dictatorship" } \\
\text { Decree Laws } 199 \text { \& } 200 \text { of } 1967 \\
\text { Decentralization \& Delegation }\end{array}$ & $\begin{array}{l}\text { "Military tutelage" } \\
\text { Law } 657 \text { of } 1965 \text { (still in effect) } \\
\text { Centralized, Weberian bureaucracy }\end{array}$ \\
\hline $1980 \mathrm{~s}$ & $\begin{array}{l}\text { "Re-democratisation" } \\
1988 \text { Constitution } \\
\text { Single Juridical Regime, Career System } \\
\text { (Weberian) }\end{array}$ & $\begin{array}{l}\text { "Neo-liberalisation" } \\
1982 \text { Constitution } \\
\text { Privatisations, Private sector practi- } \\
\text { ces in public sector }\end{array}$ \\
\hline $\begin{array}{l}\text { Turn of the mil- } \\
\text { lennium }\end{array}$ & $\begin{array}{l}\text { "Economic liberalisation" } \\
\text { Cardoso reforms (1995 - 98) } \\
\text { New Public Management ideas }\end{array}$ & $\begin{array}{l}\text { "Europeanisation" } \\
\text { EU reforms (1999 - 2005) } \\
\text { New Public Management ideas }\end{array}$ \\
\hline
\end{tabular}

Source: Elaborated by the author.

A concerted drive for the centralisation and rationalisation of the state apparatus took place under the leadership of modernising strongmen, Mustafa Kemal Atatürk (1923 - 1938) and Getúlio Vargas (1939 - 45, 1951 - 54). Under Atatürk, the newly founded Turkish Republic adopted a secular civil code based on the Swiss model and a new penal code inspired by Mussolini's Italy. The Law no. 799, enacted in 1926, officially designated civil servants as a distinct class within the state, separating them from other government employees. Laws enacted in 1927 (no. 1108) and 1929 (no. 1452) were aimed at standardising the calculation of civil servant wages and the public service budget. However, until the 1960s Turkey lacked a coherent legal framework organising the administrative structure of its growing public sector.

In Brazil, in an attempt to wrest political power from the provincial oligarchy, Vargas carried out a series of centralising administrative reforms between 1934 and 1937. The Readjustment Law of 1934 introduced a merit-based professional system, which was a mix of position and career schemes, and organised the first general classification of positions 
and salaries in the civil service. In 1937, a central agency (Departamento Administrativo do Serviço Público, DASP) was inaugurated and tasked with overseeing the organisation and management of the civil service apparatus. Yet despite the initiative for bureaucratic rationalisation, political appointments continued to supersede merit-based appointments and professional careers (GAETANI, 2008; CAVALCANTE \& CARVALHO, 2017).

During the 1960s, the Brazilian military directly and the Turkish military indirectly oversaw the implementation of far-reaching public sector reforms. The direction and the nature of the reforms enacted in the two countries, however, were different. In Brazil, the reform of 1967 was "one of the most important, widest, and most comprehensive public management reforms" the country had seen, which transformed the civil service from a centralised into a decentralised structure (GAETANI, 2008, p. 154). The Decree Laws of 199 and 200 created an "indirect" public sector alongside a "direct" one. Indirect public sector implied the delegation of authority to autonomous governmental units on the basis of private sector employment and accountancy principles. Private sector practices were expanded in the 1970s. These reforms defined the organisation of the Brazilian public sector until re-democratisation in the 1980s.

In Turkey, on the other hand, the civil service was restructured in a centralised Weberian framework. Adopted in 1960, Law no. 160 established the State Personnel Department under the Office of the Prime Minister as a centralised administrative body, tasked with overseeing the recruitment, transfer, wages, promotion and advancement of civil servants and other public sector employees. Another critical reform during this period was the adoption of the Law no. 657 in 1965 (on Civil Servants), which "deals with service, appointment, promotion requirements and features of civil servants in addition to their rights and responsibilities while acting as a civil servant", ${ }^{1}$ reorganising the civil service in a centralised career structure. Despite numerous amendments in the subsequent decades aimed at rendering the public service more inclusive of private sector practices (17 changes to the text between 2004 and 2015) and attempts to replace it altogether (in 1996, 1999 and 2005), the Law no. 657 continues to serve as the basis of public sector employment in Turkey. Instead of a coherent framework for the civil service, however, the legislation is more of a patchwork, reflecting instances of contradictory administrative philosophies.

\footnotetext{
${ }^{1}$ As stated in the notification by Turkey to the WTO at the time of the law's ratification, http://www.wipo.int/wipolex/en/ details.jsp?id=11090.
} 


\subsection{The Critical Junctures of the 1980s}

The next phase of public sector reforms in both countries took place in the 1980s, although once again the nature of change was in opposite directions. In Brazil, the end of the military dictatorship and re-democratisation provided fresh impetus for an overhaul of the public sector, which was widely perceived as having become ungovernable due to the lack of coordination among autonomous divisions, and increasingly corrupt due to the high degree of unmonitored collusion of public and private interests. The establishment of a well-functioning, disciplined and centralised 'bureaucratic elite' came to be seen as a necessary aspect of institutionalising democracy.

Correspondingly, the Constitution of 1988 ushered a return to the Weberian idea of merit-based bureaucracy, through the empowerment of the direct administration and the adoption of a Single Juridical Regime (Regime Jurídico Único, RJU) as the legal framework that continues to bind the vast majority of civil servants in the federal government today. The new arrangement limited private sector practices in the public sector, guaranteed tenure and full post-retirement benefits to civil servants, and established new classes and careers in the civil service. The 1988 Constitution also established the National School of Public Administration (ENAP) and the Centre for the Development of Public Administration (CEDAM), both under the Human Resources Secretariat (later renamed Secretariat of Personnel Management), prioritising the training and qualifications of state personnel.

In contrast, Turkey in the 1980s experienced both an intensification of the military's tutelary influence over democratic institutions and a radical shift to market liberalisation policies. Enacted after the 1980 coup, the 1982 Constitution on the one hand reaffirmed the supremacy of the military and senior bureaucracy over civilian politics, while on the other hand weakened labour laws and public sector unionisation. Privatisation schemes targeting major public enterprises were initiated and continued until the late 2000s. Although Law no. 657 was maintained with the career structure intact, the scope for hiring contractual and temporary employees from outside the public service, first introduced in 1978, was significantly expanded. 


\subsection{Economic Liberalisation and NPM at Turn of the Millennium}

As the Anglo-American-led neo-liberal economic paradigm came to dominate the post-Cold War world order, the administrative approach known as New Public Management (NPM) gained increasing international traction (OSBORNE \& GAEBLER, 1993). In the developing world, the World Bank and the IMF promoted the implementation of private sector practices, such as competition, efficiency, decentralisation, consumer-focus and market-orientation, into the public sector. NPM also became a buzzword among liberal reformers in Brazil and Turkey during the 1990s and early 2000s; a time when both countries were experiencing economic crises and acute inflationary pressures, and were prescribed market-friendly reforms in exchange for loans from international lenders. ${ }^{2}$

Reformers in both countries saw traditional bureaucracy as an administrative failure, economic burden, and contrary to the long-standing belief, an obstacle to democratic governance. In Brazil, President Fernando Henrique Cardoso (1995 - 2003), who ran on a platform of macro-economic stabilisation, trade liberalisation and privatisation, initiated a process of reform in his first term. These were spearheaded by former Minister of Finance Luiz Carlos Bresser-Pereira, who took charge of the newly established Ministry of Federal Administration and State Reform. Bresser-Pereira believed that while the military regime had failed to rid patrimonialism from the public administration, the problem was made worse when the 1988 Constitution went the opposite way to institutionalising extreme bureaucratic rigidity (BRESSER-PEREIRA, 1998, p. 239). His plan, as laid out in the 1995 Directive Plan for the Reform of the State Apparatus (PDRAE), was to transform the public administration from the bureaucratic to managerial model based on the principles of rationalisation, flexibility and publicization.

Bresser-Pereira partially succeeded in remodelling the rigid tenure system of the civil service and introducing flexible forms of employment arrangements, including private contracts. Other innovations included the generation, publication and digital management of the federal payroll, which played "a positive role in the fight against corruption", the implementation of annual public examinations for strategic careers, and the alignment of ENAP with NPM ideas in the training of public officials (OECD, 2009). However, resistance

\footnotetext{
${ }^{2}$ Brazil signed five standby agreements with the IMF between 1988 and 2002, while Turkey signed seven agreements between 1980 and 2005; www.imf.org.
} 
from labour unions, the Congress and the civil service, and limited public support for the reforms meant that the ambitious agenda could not be fully realised. The reformist drive waned in Cardoso's second term (GAETANI, 2008). Overall, the government's initiatives were more effective in shrinking the state through privatisations and decentralisation rather than transforming it: between 1989 and 2001, the number of active civil servants in the executive branch declined from 705,508 to 485,741 (CAVALCANTE \& CARVALHO, 2017), while personnel expenditures in the federal government dropped from 50 to $30 \%$ of net revenues between 1995 and 2003 (NUNBERG \& PACHECO, 2016).

Meanwhile, having already embarked on the market liberalisation path in the 1980 s, Turkish governments spent much of the 1990s pushing through major privatisation deals, while struggling to cope with economic crises and runaway inflation. A comprehensive initiative to reform the civil service only emerged until after the Helsinki Summit of the European Council in 1999, in which Turkey was formally accepted as a candidate country for European Union membership. Public administration reform, including both increasing its flexibility and efficiency (NPM) and strengthening the merit principle (Weberian), constituted a key agenda point of the EU accession process. In 2003, the newly elected Justice and Development (AKP) government initiated an Emergency Action Plan and set up a ministerial committee for Enhancing Transparency and Improving Good Governance (SOYALTIN, 2017).

Important reforms undertaken in this period include the introduction of a single examination system (Public Personnel Selection Exam, KPSS) for all public employees overseen by the State Personnel Presidency, adopted in 1999 and came into effect in 2002; the Public Finance Management Control Law (no. 5018) of 2003 that addresses issues of transparency, accountability and efficiency in the accountancy, reporting and monitoring of public finances; the Law on the Freedom to Obtain Information (no. 4982) of $2003 ;^{3}$ and the establishment under the Prime Ministry of a Council of Ethics for Public

\footnotetext{
${ }^{3}$ The text of the law in English: http://publicofficialsfinancialdisclosure.worldbank.org/sites/fdl/files/assets/law-libraryfiles/Turkey_Right\%20to\%20Information\%20Law_2004_en.pdf
} 
Services (Law no. 5176 of 2004). ${ }^{4}$ In its 2004 Progress Report, the EU recognised the "new impetus" for reforming the public sector and acknowledged that "important progress has been achieved in increasing the transparency and efficiency of public administration, including public finances" (EUROPEAN COMMISSION, 2004, p. 70).

There were also setbacks in this period. In 2005, a draft law to decentralise administrative authority was vetoed by President Ahmet Necdet Sezer on the ground that "it conflicted with the unitary character of the state" (EUROPEAN COMMISSION, 2005, p. 11). In 2006, facing popular, parliamentary and bureaucratic resistance, the AKP government abandoned a draft law aimed at replacing Law 657 on Civil Servants with a legislation that would expand the scope of hiring contract employees and introduce performance-related pay. Some of these changes were subsequently introduced in piecemeal fashion through amendments to the law 657 in 2010, the most notable of which was the introduction of experts as a new sub-category of civil servants. ${ }^{5}$ Provisions were made for the recruitment of experts in government ministries and central state agencies, against criticisms that creating specialised employment categories with decentralised recruitment procedures would violate the career and merit principles of the Civil Service Law (GüLER, 2010).

\subsection{The PT and Latter-AKP Years}

The NPM-inspired reform initiatives in the two countries gradually lost steam and were shelved by the mid-to-late 2000s. In Brazil, the election of Luiz Inácio Lula da Silva as president in 2002 signalled a return to the traditional view of bureaucracy. ${ }^{6}$ The federal government played a central economic role under the PT administrations, with

\footnotetext{
${ }^{4}$ Between 2005 and 2016, the Council received 2092 complaints, of which it investigated 545. It found a violation of ethics norms in 83 cases. Top claims were "incompliance with general ethical standards", "corruption, unlawfulness", "negligence, breach of duty", and "favouritism, nepotism and discrimination." The Council's lack of punitive authority, however, limited the efficacy of its decisions (AKDENIZ, 2016, p. 67). Another criticism concerned the narrow scope of the Council's authority, exempting politicians, military, judicial and academic personnel. (ÖMÜRGÖNÜLŞEN, 2009). See: http://etik.gov.tr.

${ }^{5}$ Although the introduction of this sub-category was presented as an attempt to overcome the arbitrarily broad categorisation of civil servants under Law 657, the SPP also defined "experts" in a rather vague and expansive manner, as those professions involving duties of "producing strategies, researching, planning, programming, administration and inspection and who exercise power".

${ }^{6}$ Despite its anti-neoliberal discourse, however, the PT governments did not completely move away from the previous administration's agenda, including the decentralisation of social policy to local governments, privatisation of public services, reform of the pension system and introduction of performance management policies (CAVALCANTE, 2018, p. 889).
} 
social spending and subsidies featuring prominently in the developmentalist agenda of presidents Lula and Dilma Rousseff. Parallel to the expansion of social services and the establishment of new ministerial portfolios, the number of civil servants in the executive branch, particularly in senior managerial positions (DAS-4 to 6) increased significantly, from 485,741 in 2001 to 613,639 in 2014 . There were also changes in the wages of civil servants, reflecting Brazil's economic growth pattern: 230\% actual increase between 2003 and 2010 , followed by an actual decrease (despite nominal increase) due to inflationary pressures (CAVALCANTE \& CARVALHo, 2017, p. 11-15).

Finally, the PT era saw considerable advances in the legal and administrative provisions for the transparency and accountability of the public sector, with the Office of the Comptroller General (CGU) playing a prominent role in the process. These include, among others, the adoption of the Freedom of Information Act of 2012 and the appearance of the Transparency Portal, which publicises public sector data, including the salaries of public officials (CORRÊA, 2016).

President Rousseff's politically charged impeachment and replacement by vice president Michel Temer in 2016 signalled a shift towards market-friendly socio-economic policies. While Temer's historically low public backing prohibited his administration from launching a comprehensive public administration reform policy, the 20-year public spending freeze that the government locked into the constitution in late 2016 (PHILLIPS, 2016) and the pension reform introduced in the Congress that was finally adopted under his successor, president Jair Bolsonaro, are likely to have long-term impacts on the Brazilian public administration (SоTо, 2016).

In Turkey, the pace of reforms declined parallel to the loss of steam in the country's accession process to the EU from the mid-2000s onwards. Even with the reforms that were passed, implementation remained problematic. After the AKP's third general election victory in 2011, the government took a sharp turn towards illiberal governance. It also increasingly became evident that the AKP was pushing through reforms not so much with the end goal of democratisation, but rather with the aim of capturing key state institutions from what it viewed as a hostile "bureaucratic oligarchy" (SOMER, 2016). In early 2014, a high level corruption scandal broke out involving top AKP officials and senior bureaucrats with ties to the ruling party. The government suppressed the investigation 
and purged prosecutors and police officers pursuing the case, who were linked to the Hizmet Movement, an influential religious network linked to US-based Islamic preacher Fethullah Gülen, a former political ally-turned-enemy of President Recep Tayyip Erdoğan.

The picture deteriorated dramatically after the failed military coup attempt of 15 July 2016, which was followed by the declaration of a State of Emergency and the mass purges of suspected government opponents from all levels and categories of the public service. ${ }^{7}$ In its 2018 Progress Report, the European Commission warned of a "serious backsliding" in the fields of public service and HRM, stating "no effective remedy has been provided for large-scale dismissals or in relation to the administration's accountability." The Commission also noted that there was "still neither a comprehensive public administration reform strategy nor political ownership of this reform" (EUROPEAN COMMISSION, 2018).

\section{The Civil Service in Brazil and Turkey Today}

Table 2 below outlines the key characteristics of the civil service in Brazil and Turkey. $12 \%$ of the workforce in Brazil and 13\% in Turkey are employed in the public sector; both below the OECD average of $19 \%$. In Brazil, the Secretariat of Personnel Management (SPM), based within the Ministry of Planning, Development and Management, is the body responsible for defining HRM practices. ${ }^{8}$ The SPM sets and oversees pay systems, budget allocation (which is presented by ministries and approved by the Congress) and post distributions. It manages recruitment and dismissal of public officials. The SPM also coordinates working conditions, performance appraisal, the code of conduct and equal opportunity issues. Despite this highly centralised structure, however, there are significant differences between employment contracts across ministries (OECD, 2012). In Turkey, the State Personnel Presidency (SPP) had the central coordination responsibility for HRM practices until it was dissolved in 2019 and had its responsibilities transferred to the General Directorate of Labour, based within the Ministry of Family, Labour and Social Services.

\footnotetext{
${ }^{7}$ At the time of writing, over 150,000 state employees had been suspended or dismissed, with over 50,000 people (including journalists, businesspeople, NGO workers, politicians alongside public servants) in prison (DALHUISEN, 2017).

${ }^{8}$ The agency was known as the Human Resources Secretariat until 2017.
} 
In Turkey, the Law no. 657 divides public employees into three broad categories (civil servants, contract employees and workers) and 12 classes. ${ }^{9}$ A government-sponsored "Public Administration Research Report" in 1991 stated that the "broad coverage classification system lumps together different careers and areas of expertise without regard for their particular characteristics and the need for different personnel procedures" (TODAIE, 1991). This criticism has been echoed in numerous OECD and EU reports on HRM practices in the Turkish public administration. ${ }^{10}$

In contrast to Turkey, there are over 250 established careers within the public administration in Brazil. While the Weberian idea of centrally-organised, career-based bureaucracy remains the legal/structural basis of public administrations in Brazil and Turkey, both countries have also introduced various forms of flexible and non-permanent employment options and private sector practices in their civil service over the past decades. As discussed above, Turkey has embarked upon market liberalisation and NPMbased public administration reforms earlier than Brazil in the 1980s, and arguably pursued them more eagerly since. The outcome of their divergent paths becomes visible when we take a comparative look at some of the core characteristics and performance indicators of the two public administrations.

\footnotetext{
${ }^{9}$ For full text of the law see (in Turkish): https://www.mevzuat.gov.tr/MevzuatMetin/1.5.657.pdf

10 "The Law on Civil Servants defines public service in a way that is extremely broad", says the European Commission in its Turkey Progress Report, 2016, p. 15.
} 
Table 2 | Structural Characteristics of the Civil Service

\begin{tabular}{|c|c|c|}
\hline & Brazil & Turkey \\
\hline No. of Civil Servants & $\begin{array}{l}\text { 633,003 (PEP, Feb 2018) } \\
\quad \text { (federal level only) }^{11}\end{array}$ & $\begin{array}{l}2,449,538 \text { (SPP, Sept 2017) } \\
\text { (all levels - unitary state) }{ }^{12}\end{array}$ \\
\hline$\%$ of workforce (2013) & 12 (inc. municipal and state) & [OECD average: 19\%] \\
\hline Central HRM Body & $\begin{array}{c}\text { Secretariat of Personnel Manage- } \\
\text { ment } \\
\text { (Ministry of Planning, Develop- } \\
\text { ment and Management) }\end{array}$ & $\begin{array}{l}\text { General Directorate of Labour } \\
\text { (Ministry of Family, Labour and } \\
\text { Social Services) }\end{array}$ \\
\hline Recruitment system & Mainly career based & Mainly career based \\
\hline Legal framework & $\begin{array}{l}\text { Single Juridical Regime (Law } 8112 \text { ) } \\
\& \text { the Consolidation of Labour } \\
\text { Laws. Fixed term contracts gover- } \\
\text { ned by Law } 8745 / 93 \text {. }\end{array}$ & $\begin{array}{c}\text { Law } 657 \text { divides employees in } 3 \\
\text { categories: } \\
\text { Public Servants, Contract Em- } \\
\text { ployees, Workers }\end{array}$ \\
\hline Recruitment process & $\begin{array}{l}\text { Formal competitions. Quota for } \\
\text { blacks and disabled persons. }\end{array}$ & $\begin{array}{c}\text { Centralised written exam (+oral } \\
\text { interview). Quota for disabled } \\
\text { persons. }\end{array}$ \\
\hline $\begin{array}{l}\text { Promotion / Advance- } \\
\text { ment }\end{array}$ & $\begin{array}{l}\text { Adv. is automatic based on years } \\
\text { in service. Promotion based on } \\
\text { performance, years in service, } \\
\text { educational qualifications. }\end{array}$ & $\begin{array}{c}\text { Adv. is automatic based on years } \\
\text { in service. Promotion based on } \\
\text { performance (high importance), } \\
\text { years in service, educational } \\
\text { qual. }\end{array}$ \\
\hline $\begin{array}{l}\text { Wage } \\
\text { calculation }\end{array}$ & $\begin{array}{c}\text { Compartmentalized collective } \\
\text { bargaining }\end{array}$ & Centralized collective bargaining \\
\hline Right to Unionise / Strike & Yes / Yes & Yes / No \\
\hline
\end{tabular}

\footnotetext{
${ }^{11}$ The total number of civil servants in Brazil is around 8.6 million, with $4.9 \mathrm{~m}$ employed at the municipal and $2.6 \mathrm{~m}$ at the state levels. The executive branch accounts for $81 \%$ of all civil servants in the federal government, followed by the judiciary (15.2\%) and the legislative (3.6\%).

12 Other centrally recruited public employees in Turkey are judges and prosecutors $(17,400)$, teaching staff $(128,277)$, contract employees $(163,800)$, workers $(320,591)$, temporary personnel $(20,363)$, and military personnel $(241,389)$. Total number of public employees as of September 2017 is 3,341,358. It was not clear whether this number included employees suspended after the 2016 coup attempt.
} 
Brazil
Post-2019 reform fixed minimum age: $65(\mathrm{~m}) ; 62(\mathrm{~m})$

Retirement

Private sector: Min. contribution of 15 yrs (w); 20 yrs (m)

Public sector: Min. contribution of 20 yrs ( $m \& w)$

Pre-2003 entries to civil service:

Full final salary in retirement.

Pension Benefits Post-2003 entries: $60 \%$ of average salary after minimum contribution; rising $2 \%$ each additional year.

\section{Turkey}

Pre-2008 entry: 60(m); $58(\mathrm{w})$.

Post-2008 entry: 60-65 (m); 58-

$65(w)$

(25 years of min. insurance contribution)

Pensions indexed to CPI, means-tested.

Civil servants receive approx. 50$70 \%$ of salary in retirement

Source: PEP, SPP, OECD.

\subsection{Government Efficiency and Effectiveness}

Perceptions of systemic corruption (both petty and high level), bureaucratic inefficiency and lack of trust in institutions have long been causes of public discontent in Brazil and Turkey. Correspondingly, the two countries launched periodic initiatives to stem corruption, increase public trust in institutions and enhance efficiency in governance. These efforts were often responses to popular backlash and/or international pressures following high profile corruption scandals or economic crises. Turkey's financial crisis in 2001-2002 initiated the IMF-imposed structural reforms in the country's banking system and macroeconomic policy, and led to a political earthquake that brought to power the AKP as a single party, promising economic growth, eradicating corruption and improving social services.

For nearly a decade under the AKP governments, perceptions inside and outside Turkey regarding corruption, public trust in institutions and government efficiency improved steadily. Although this trend gradually slowed down and was decisively reversed in the 2010s, when it comes to perceptions of government effectiveness and control of corruption, Turkey's overall record in the past 15 years still appears brighter than that of Brazil (Chart 1). For 2016, Turkey was ranked Turkey 54 ${ }^{\text {th }}$ among 192 countries in the World Bank's Government Effectiveness index, while Brazil came $95^{\text {th }}$. 


\section{Chart 1 | Government Effectiveness and Control of Corruption}

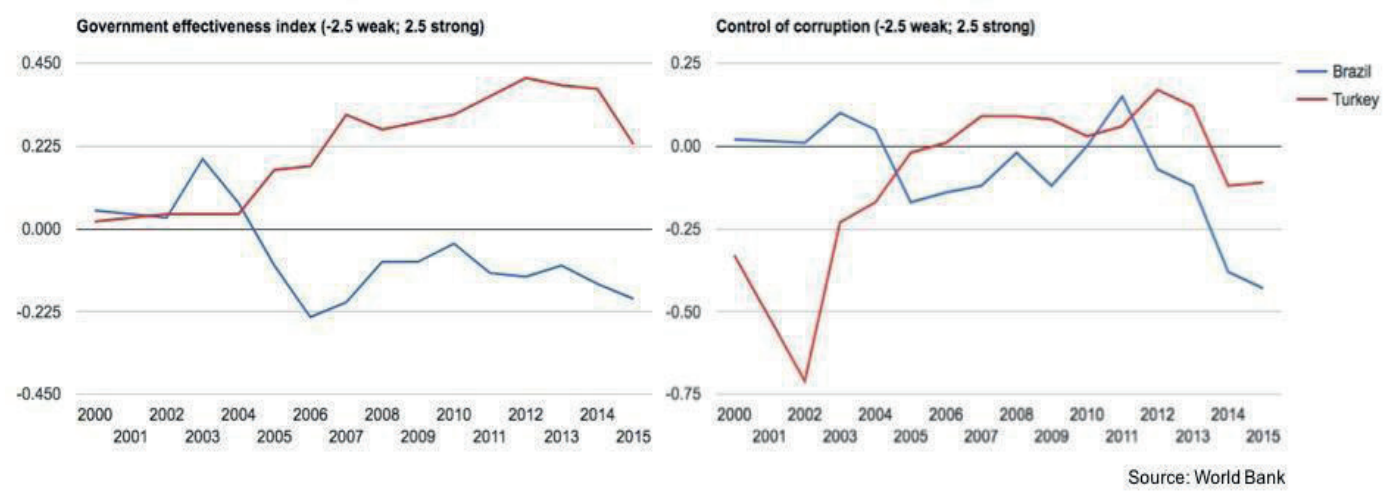

According to the Inter-American Development Bank, Brazil was the only country in the region, besides Honduras, where government efficiency deteriorated between 2004 and 2013 (VELARDE et al., 2014). ${ }^{13}$ Although the causes of this retrenchment are not discussed in the study, it is likely to be attributed to the growing role of the federal government as a political and economic actor, and the accompanying increase in the size and budget of the civil service during the 2000s. (In the same period, the greatest improvement was observed in Chile, which implemented extensive market liberalisation policies and NPM-based public administration reforms.) During this period, Brazil also witnessed the eruption of two major corruption scandals, the vote-buying scandal (Mensalão) of 2003 and the Car Wash investigation in 2014, which were influential in shaping domestic and international perceptions of government efficiency and effectiveness.

Another metric widely used to gauge government efficiency is the World Bank's Ease of Doing Business index, in which Turkey was ranked $60^{\text {th }}$ and Brazil $125^{\text {th }}$ among 190 countries as of January 2018. More specifically, Turkey is ranked $46^{\text {th }}$ and Brazil $131^{\text {st }}$ for registering property, and $80^{\text {th }}$ and $176^{\text {th }}$ respectively for the ease of starting a business, which can be viewed as indicators for bureaucratic efficiency. ${ }^{14} \mathrm{~A}$ similar picture emerges from the World Economic Forum's Global Competitiveness Report for 2017 - 2018, which paints a bleak overall picture of Brazil's public institutions.

\footnotetext{
${ }^{13}$ IDB still ranked Brazil third in the region for government efficiency, after Chile and Colombia. However, only Chile was credited for having a high level of government efficiency.

${ }^{14}$ World Bank, Doing Business Rankings, June 2017: http://www.doingbusiness.org/rankings.
} 
Table 3 | Performance of Public Institutions

\begin{tabular}{|l|c|c|}
\hline Category & Brazil rank (out of 137)/trend & $\begin{array}{c}\text { Turkey rank (out of 137)/ } \\
\text { trend }\end{array}$ \\
\hline Country rank (overall) & $80 / \uparrow$ & $55 / \downarrow$ \\
\hline Institutions (overall) & 109 & 71 \\
\hline Public trust in politicians & 137 & 70 \\
\hline Diversion of public funds & 134 & 38 \\
\hline Irregular payments \& bribes & 107 & 53 \\
\hline Favouritism in govt decisions & 112 & 82 \\
\hline Efficiency in govt spending & 133 & $38(2016-17)$ \\
\hline Transparency of govt decisions & 127 & 42 \\
\hline
\end{tabular}

Source: WEF 2017- 2018 Report

Brazil comes last among 137 countries for "public trust in politicians" and near the very bottom for "diversion of public funds", "efficiency in government spending", and "transparency of government decision making". Turkey is ranked more favourably in all these categories. Its most problematic assessment is "favouritism in government decisions", which points to enduring practices of political clientelism and lack of transparency in government-sponsored tenders, contracts and appointments. The picture changes somewhat when looking at the most recent trend, with slight improvement noted in perceptions of public sector corruption in Brazil after 2015, as opposed to rapid deterioration in Turkey.

Finally, corruption and bureaucratic inefficiency were listed among the top obstacles to doing business in Brazil by the WEF Executive Opinion Survey 2016. While inefficient government bureaucracy was also viewed as a major concern for businesses in Turkey, corruption only came fourteenth with $2.7 \%$ of respondents citing it as a problem for doing business in the country. 
Table 4 | Obstacles to Doing Business

\begin{tabular}{|l|l|}
\hline Brazil & Turkey \\
\hline 1. Tax rates & 1. Inadequately educated workforce \\
\hline 2. Corruption (13.6\%) & 2. Access to financing \\
\hline 3. Tax regulations & 3. Inefficient govt bureaucracy $(10.5 \%)$ \\
\hline 4. Inefficient govt bureaucracy (11.9\%) & 4. Political instability \\
\hline 5. Political instability & 5.Tax rates \\
\hline & ...14. Corruption $(2.7 \%)$ \\
\hline
\end{tabular}

Source: WEF Executive Opinion Survey 2016

Having pursued market liberalisation reforms, including NPM practices in the public sector, more thoroughly and over a longer time span than Brazil, it is perhaps little surprise that Turkey ranks higher than Brazil in most measurements of government efficiency, which can also be read as a measurement of institutional liberalisation. Although many of the reforms Turkey enacted in the early 2000s (to curb corruption, improve government transparency, strengthen the rule of law and uphold civil liberties) have since been rolled back, the government has maintained its open-door policy to businesses and foreign investment, which helps explain its comparatively positive evaluation by the international business community, reflected in the WEF Executive Opinion Survey.

This, however, also points to a methodological issue undermining these measurements, namely the outsized role corporate perspectives play in gauging government efficiency. In terms of the regulatory environment, the interests of the private sector and the general public do not automatically overlap. What is seen as a needless bureaucratic burden by the private sector might have a public interest and democratic accountability justification. Hence, the pro-business perspective in these studies may have a distorting effect on perceptions of government efficiency (VAN DE WALLE, 2006). Another methodological issue is the fact that the rankings conflate multiple variables in a single score, obscuring potentially significant differences between variables, making it more difficult for observers to pinpoint the performance of the civil service. ${ }^{15}$ Similarly, in

\footnotetext{
${ }^{15}$ World Bank's government effectiveness index, for example, includes variables such as the quality of primary education, satisfaction with roads and highways and the coverage area of the electricity grid, besides quality of bureaucracy and institutional effectiveness.
} 
decentralised administrative systems like Brazil, the structure, resources and the quality of public services may vary between municipal, state and federal levels. Such limitations should be taken into consideration when using these metrics as determinants of civil service performance.

\subsection{Merit and Professionalism}

If efficiency has been the buzzword for NPM-based public administration reforms since the 1980s, merit has been the central tenet of modern bureaucracies since the Napoleonic era. In their "Weberianness scale", measuring meritocratic recruitment and predictable career progression in the civil service, Evans and Rauch (1999) ranked Brazil $18^{\text {th }}$ and Turkey $21^{\text {st }}$ out of 35 developing countries for the period of $1970-1990 .{ }^{16}$ The latter years of the research correspond to the period when Turkey had started introducing private sector practices to its bureaucracy, while Brazil was restructuring its decentralised public administration in a merit-based centralised framework. As noted above, these trends continued into the 1990s and the early 2000s.

After 1988, Brazil further developed and institutionalised the career structure of the civil service, with rigorous examination criteria applied in the recruitment and promotion of civil servants in core careers of the federal executive. As a result, the Brazilian federal civil service has long been viewed as the most developed in Latin America, with a meritocratic system in a continuous process of professionalisation. The Inter-American Development Bank (IDB) ranked Brazil as the most meritocratic civil service in the region in both 2004 and 2011-2013, with a score of 93 out of $100 .{ }^{17}$ Brazil was the only country to score high on this index, indicating "open recruitment based on suitability, with guarantees against arbitrariness; hiring based on competence using valid instruments; mechanisms for ingress, promotion, absenteeism, discipline; and non-arbitrary firing on the basis of

\footnotetext{
${ }^{16}$ The "Weberianness scale" was created out of expert questionnaires in 35 developing countries in Africa, Latin America, Europe and Asia. On a range of 0 to 14, highest scoring countries were Singapore (13.5), South Korea (13), Taiwan (12) and Hong Kong (11), and the lowest scoring were Kenya (1), Dominican Republic (2), Nigeria (3) and Guatemala. Brazil and Turkey scored 7.6 and 7.0, respectively.

17 The IDB's Merit Index "measures professionalism in the functioning of the civil service system and the degree of impartiality of the decisions within each management subsystem. More specifically, the Merit Index measures the degree of effective protection that the system offers against arbitrariness, political capture, clientelism and the different methods of rent seeking by interest groups or sectors" (VELARDE et al., 2014, translation by author).
} 
performance" (GRINDLE, 2010). It should be noted that in its 2014 report, the IBD noted that the process of consolidation showed less dynamism than in the past (VELARDE et al., 2014, p. 26).

This is not to suggest that political patronage, a legacy of patrimonialism in the Brazilian public administration, is no longer an issue. As the indicators on government efficiency and effectiveness also suggest, patronage-linked corruption remains a concern especially in high level appointments to the civil service. According to Decree 9,021 of 2017 , up to $50 \%$ of total positions in DAS levels 1 to 4 , and $40 \%$ of positions at DAS levels 5 and 6 can be occupied by external appointees. ${ }^{18}$ At the highest levels, appointments and dismissals are influenced by the president and ministers, while the ministers and other officials have influence over that of lower management levels (OECD, 2012). The distribution of strategic positions in exchange for political support is key in a fragmented political system, where more than two dozen parties are represented in the Congress. Thus, as Oliveira (2017, p. 19) argues, it is no surprise that cases of corruption and mismanagement of state companies and other organisations almost always involve political appointees.

Despite enduring patrimonialism, in the few comparative rankings available, Brazil outperforms Turkey on the relevant criteria. In the Quality of Government Institute's expert survey on the structure and behaviour of public administrations, Brazil is ranked $32^{\text {nd }}$ and Turkey $57^{\text {th }}$ globally (out of 156 countries) for civil service professionalism. In the civil service impartiality measurement, Brazil is ranked slightly above Turkey, $46^{\text {th }}$ to $49^{\text {th }}$ respectively (DAHLSTROM et al., 2015). Although Turkey made advancements in promoting merit in the recruitment of civil servants with the adoption of the Public Personnel Selection Exam in 1999, implementation has remained problematic and there are signs of widespread political patronage in the public sector in recent years.

The politicisation of the entire public administration - not just senior management continues to be "of serious concern" in Turkey (EUROPEAN COMMISSION, 2018). A particular problem is the widespread use of poorly regulated, non-transparent oral interviews as a means to bypass the centrally-organised exams in the recruitment and promotion of civil servants (EUROPEAN COMMISSION, 2016, p. 15). Numerous cases were reported in the

\footnotetext{
${ }^{18}$ Previously, this was 25\% for DAS-1 to 3 and 50\% for DAS-4 to 6, based on Decree 5497 of 2005.
} 
Ministry of Education, the Ministry of Finance, the Prime Ministry, the State Radio and Television and the Postal Service about successful candidates being eliminated in the oral stage due to their political orientation or religious backgrounds. Another violation of the merit principle in the recruitment process in Turkey is the mass conversion of temporary contracts into permanent civil service positions, often used as a populist pre-election strategy by politicians. Shortly before the 2011 general election, the status of around 200,000 (out of the existing 260,000 ) contract workers were converted into permanent positions. A further 100,000 contract employees became civil servants in 2013, ahead of the presidential election the following year. Instead of taking the centrally organised entrance exam, these employees only had to pass oral interviews conducted within their institutions (HABERLER, 2014).

Finally, the lack of accountability and due access to legal process in large-scale dismissals in the aftermath of the post-2016 coup attempt constitute a major breach of the merit principle, as well as rule of law in Turkey. Citing exceptional circumstances, the government also reportedly allowed a large number of ministries and departments to bypass the central examination to hire thousands of civil servants through oral interviews in order to replace those dismissed in the purges (YENI ÇAĞ, 2016).

\subsection{Rights and Benefits}

Considerable differences strike attention when comparing the Brazilian and Turkish civil services for public sector wage calculation, industrial rights and retirement/pension schemes. These differences can be seen as a reflection of both the directions that the two public administrations evolved after the 1980s, as well the political orientation and policies of the PT and AKP governments in the 2000s.

\subsubsection{Wage Calculation}

In Brazil, the wage bargaining process is formally conducted by the Secretariat of Personnel Management, which is part of the Ministry of Planning, Development and Management. However, the political weight of each career and ministerial power plays an important role in determining the outcome of these processes. This can lead to inconsistencies between the salaries of public officials at comparable levels in different 
careers due to imbalances in the bargaining powers of different ministries and unions. In Turkey, base salary calculations are negotiated through comprehensive collective bargaining, often encompassing both the public and the private sectors simultaneously (organised by Law no. 6356 of 2012). Collective bargaining involves meetings, usually every two years, between officials from the Ministry of Family, Labour and Social Security, and representatives from employer unions (for private sector negotiations) and the largest trade confederations.

As noted previously, net public official wages increased by $230 \%$ in Brazil between 2003 and 2009. This was an outcome of the growing economy as well as the PT government's close ties with labour unions, and was justified on the basis of the necessity to compete with the private sector. In 2017, a World Bank study found that federal civil servants in Brazil earned $67 \%$ more than private sector employees in a similar role, training and experience; the highest difference in a sample of 53 countries surveyed. According to the Bank, this contributed to inequality in the country, with $54 \%$ of Brazil's civil servants being placed among the wealthiest 20\% (OTA \& FERNANDES, 2017).

In 2015, the total public sector wage spending in Brazil (comprising federal, state and municipal governments) amounted to $13.1 \%$ of the GDP, compared to $9 \%$ in the United States, 6.4\% in Chile and around 8\% in Turkey (World Bank 2017). Despite making up a small minority of civil servants in all three levels, federal government wages were responsible for a disproportionate amount of this spending, accounting for between 4 to 5\% of the GDP alone between 2001 and 2014 (Table 6). Within the federal government, average salaries of civil servants in the judiciary and the legislature were almost twice that of public officials in the executive branch. Finally, within the federal executive itself, a significant wage gap existed between the strategic core careers and the general civil service, with the average wage of the latter being $29 \%$ of the former (CAVALCANTE \& CARVALHo, 2017, p. 10). 
Table 5 | Civil Service Wages

\begin{tabular}{|c|c|c|}
\hline & $\begin{array}{c}\text { Brazil } \\
\text { (PEP, 2017) }\end{array}$ & $\begin{array}{c}\text { Turkey } \\
\text { (SPP, 2017) }\end{array}$ \\
\hline Highest Salary & $\mathrm{R} \$ \begin{array}{c}\text { 29,133.55 (Superior level) } \\
{[\text { [USD 9,006.35] }}\end{array}$ & $\begin{array}{c}\text { TL 10,852.40 } \\
{[\text { USD 2,874] }}\end{array}$ \\
\hline [Feb 2018 USD] & R\$ 1,467.49 (Auxiliary level) & TL 2,829.84 \\
\hline Lowest Salary & {$[$ USD 453.65] } & \\
\hline [Feb 2018 USD] & & \\
\hline Wages \% of GDP & $4-5$ (federal gov) \\
(World Bank Dataset 2015) & $13.1 \%$ (total) & $7-8$ \\
\hline
\end{tabular}

Source: PEP, SPP.

A striking contrast between Brazil and Turkey is in wage brackets. While the maximum salary of a civil servant in Brazil was nearly three times the maximum salary of a Turkish civil servant as of early 2018, employees in the lowest end of the salary scale in Turkey earned more than their Brazilian counterparts, revealing a significant salary gap between high and low earners in the Brazilian public sector. The difference between civil servant salaries in Brazil and Turkey becomes even wider when additional benefits are factored in, which tend to be more generous in Brazil, particularly in elite careers (ROMERO, 2013).

\subsubsection{Industrial Relations}

Comparing industrial relations in Brazil and Turkey reveals another stark contrast between the two countries. In Brazil, trade union density in the general workforce is around $19 \%$ and unions have a collective bargaining cover of $60 \%$ (CNM, 2012). Around $55 \%$ of the public officials in the federal executive are unionised (OECD, 2012). The right of Brazilian public service employees to join unions and to strike is enshrined in the 1988 Constitution. ${ }^{19}$ Unions have played an important role in negotiating public employees' salaries and rights since re-democratisation, especially under the PT governments. An important step in the protection of workers' rights and workplace standards was taken in 2010 when the Brazilian Congress ratified ILO's Convention 151 and Recommendation 159. Strikes are common in the Brazilian civil service, with one study showing that civil

\footnotetext{
${ }^{19}$ Civil servants working directly in the area of public security are not entitled to strike.
} 
servant strikes (across federal, state and municipal levels) amounted to $45.3 \%$ of all recorded strikes in the country between 2002 and 2012 (PICHLER \& MENEGOTTO, 2015).

In Turkey, in contrast, trade unions have been heavily suppressed and weakened since the 1980s. Civil servants in Turkey can join unions but they are constitutionally prohibited from organising or supporting any industrial strike action. Public officials taking part in strikes can face disciplinary measures. ${ }^{20}$ The sharpest decline in unionisation took place under the AKP governments, due to the "gradual legalization of various forms of precarious and temporary work, especially under the subcontracting schemes" (YABANCI, 2016 , p. 600). While $29 \%$ of the general workforceas unionised in 2001 , this number had fallen to $8 \%$ by 2015 ; significantly below the $17 \%$ OECD average. Furthermore, only $7 \%$ of

Given this background, it might seem surprising that more than two-thirds of public servants in Turkey are unionised and that public sector unionisation increased by 149\% between 2002 and 2016. This is almost exclusively due to the sharp increase in the membership of a single union, Memur-Sen, which was a relatively young and small civil service union before the emergence of the AKP in 2002. Unlike Turkey's most established civil service confederation KESK, which is independent from the government, conservative Memur-Sen has close ties with the AKP both in terms of cadres (several of its former leaders ran on the AKP ballot to become MPs) and its socially conservative-economically liberal political discourse. Between 2002 and 2016, while membership in the left-leaning KESK fell by 16\%, Memur-Sen's membership increased from 42,000 to 936,000 (a 2,129\% increase) as a result of "co-optation and intimidation strategies that oblige workers and civil servants to quit their previous trade unions or recruit non-associated workers as members of preferred trade union" (YABANCI, 2016, p. 601). In turn, the government has designated Memur-Sen as its main interlocutor at the collective bargaining stage and favoured it through relevant legislation (ERDINç, 2014).

\subsubsection{Retirement and Pension Schemes}

For years, Brazil enjoyed a more generous retirement and pension scheme compared to Turkey and the OECD average. Until the 2019 pension reform, there was no

\footnotetext{
${ }^{20}$ In a number of instances these measures have been repealed by the Court of State, creating an ambiguous legal environment where striking is both prohibited and often practically tolerated.
} 
fixed minimum age for retirement; men could retire after 35 years and women after 30 years of contribution to the system. Those who contributed for 15 years could retire at the age of 65 for men and 60 for women. ${ }^{21}$ In 2018, the average retirement age in Brazil was 56 for men and 53 for women. Pensions of retired civil servants from the Single Juridical System (RJU) are adjusted by the same indexes that are applied to the wages of active civil servants. The pensions of public employees hired under the Consolidated Labour Laws are readjusted by the indexes of the social security system. Under the pre-2019 system, all pension recipients received at least the minimum wage and most civil servants continued to receive their full final salary after retirement. The pension and social assistance system in Brazil cost over 10\% of the GDP in 2016 (OECD, 2017).

The pension reform accepted in Congress in November 2019 introduced a fixed retirement age of 65 for men and 62 for women, and a minimum insurance contribution period of 15 years for women and 20 years for men in the private sector, and 20 years for all in the public sector. ${ }^{22}$ The reform also significantly reduced pension benefits for civil servants (with the exception of the military, which has maintained its privileges), with those who entered the service after 2003 being entitled to receive $60 \%$ of their average career salary after 20 years of contribution, with a $2 \%$ increase for each additional year of contribution. Under the new scheme, a public servant can receive their full salary in retirement only after 40 years of contribution to the system.

In Turkey, for those who entered the social security system before October 2008, the minimum retirement age is 60 for men and 58 for women. For those who enter the system after October 2008, retirement age gradually increases to 65 for men and 65 for women. The minimum contribution period is 25 years. In 2016, the public pension spending was $8.1 \%$ of GDP, in line with the OECD average. Pensions are indexed to CPI, updated twice a year in January and July. Pensions are means-tested and payable only to those who are either disabled, over 65 years old or receive no other social security benefits. A rough calculation of average public salaries to pensions suggests that civil servants in Turkey receive about 50 to $70 \%$ of their working salary as pension in retirement.

\footnotetext{
${ }^{21}$ The OECD average for minimum contribution is 26 years.

${ }^{22}$ Emenda Constitucional № 103, 12 November 2019, http://www.planalto.gov.br/ccivil_03/constituicao/emendas/emc/ emc103.htm.
} 


\subsection{Demographic Representation and Gender Balance}

Although a majority of Brazil's population is categorised as non-white, white Brazilians are overly represented in the private sector, politics and the public sector, especially in high managerial positions; a reflection of the racial subtext of the country's embedded socio-economic inequality (MANEO \& AMÂNCIO, 2015; VOLPE \& SILVA, 2016). A nationwide recruitment quota for blacks was only introduced in 2014. According to Law No. 12,990 of 9 June $2014,20 \%$ of the vacancies offered in public tenders and public jobs in the federal public administration, municipalities, public foundations, public companies and mixed economy companies controlled by the federal government should be reserved for black citizens. The Brazilian federal law also requires institutions and companies with over hundred employees to fill 2 to $5 \%$ of their positions with persons with disabilities. Similarly, in Turkey, as of 2011, public institutions are required to have a $3 \%$ quota for disabled employees.

Underrepresentation of women in the civil service remains a serious problem in Turkey, where women occupy only a third of all public service posts and less than $8 \%$ of senior management positions. In contrast, women hold a majority of public offices in Brazil, in line with the OECD average. Although they are also underrepresented in senior management, particularly at the highest level (DAS-6), the percentage of women in senior management in Brazil is considerably higher when compared to Turkey and (considering DAS-5 \& 6) also above the OECD average (CAVALCANTE \& CARVALHO, 2017).

\section{Table 6 | Women in Public Service}

\begin{tabular}{|c|c|c|c|}
\hline $\begin{array}{c}\text { Women in Public } \\
\text { Service }\end{array}$ & Brazil & Turkey & OECD Average \\
\hline \% in public service & 59.29 & 33.8 & 58.35 \\
\hline $\begin{array}{c}\text { \% in senior manage- } \\
\text { ment }\end{array}$ & $\begin{array}{c}21.8 \text { (DAS-6) } \\
41.1 \text { (DAS-5 \& 6) }\end{array}$ & 7.98 & 32.37 \\
\hline
\end{tabular}

Source: OECD 2015 


\section{Conclusion}

The Brazilian and the Turkish public administrations display a mix of patrimonial, traditional bureaucratic and managerial characteristics. This patchwork is a result of more than a century of disjointed reform attempts to address chronic institutional problems such as government inefficiency, political patronage and corruption. Both public administrations continue to face these challenges today, albeit in different forms and degrees: government inefficiency comes across as more of a problem in Brazil, while the deterioration of the merit principle and resurgence of political patronage are particularly disconcerting in Turkey. Public sector employees enjoy more limited rights and benefits in Turkey than in Brazil, where the civil service is faced with the opposite charge of constituting a privileged class in a highly unequal society. Finally, while corruption remains a serious issue in both cases, the causes of it appear to be different.

The architects of Brazil's re-democratisation went on to strengthen the centralised career-based structure of the civil service, while Turkey embarked upon extensive market liberalisation reforms following its 1980 coup. As a result, the Brazilian civil service, in particular the career structure in the federal level, has long been considered the most professionalised and meritocratic in the region. Highly competitive salaries, labour laws favouring employees, a well-established career structure and, until 2019 a generous pension system attracted qualified Brazilian men and women, who would otherwise seek private employment, to public service. The downside of this has been the emergence of a privileged class in a notoriously unequal country. In pushing the pension reform of November 2019, the Bolsonaro government claimed it was ending these privileges, although the scheme has received criticism for actually preserving benefits of the most privileged groups, in particular the military. Furthermore, the low representation of black Brazilians in the civil service, the recent implementation of the quota system notwithstanding, shows that the public administration is not immune to the wider causes of this socio-economic inequality. A similar case can be made for the under-representation of women in the Turkish civil service.

The high level of meritocracy and professionalism which Brazil succeeded in institutionalising has not translated into achieving similar levels of government efficiency 
and effectiveness. In Turkey, the problem appears to be the opposite: pursuing businessfriendly macroeconomic policies and NPM-based public administration reforms, successive Turkish governments attempted to create a more flexible, efficient and result-oriented public service, in large part through weakening labour laws and co-opting public sector employees. A wide array of liberalising reforms was adopted at the height of Turkey's EU membership process from the late 1990s until mid-2000s. Ultimately, however, enthusiasm for free market policies, coupled with an ideological contempt for bureaucracy under the AKP governments, resulted in the dramatic deterioration of the merit principle and the pervasive use of political patronage throughout the civil service.

Political patronage also remains an entrenched problem in Brazil, but as noted above, its causes appear to be of a different nature than in Turkey. In Turkey, the recent picture is a result of the domination of the political system and key public institutions by a single political party, which has prioritised capturing the state over democratising it. In contrast, one of the proposed explanations for enduring patronage in Brazil is the country's fragmented political system, where strategic posts are dished out to curry favours from the high number of small parties making up the federal parliament. This difference also goes to the root of high level corruption in both countries. Ultimately, if the legal and institutional improvements in transparency and accountability of the public sector achieved in Brazil during the 2000s can be protected, there would be reason for hope going forward. It is more difficult to find a cause for optimism in the case of Turkey given its rapid de-democratisation, which Freedom House (2018) labelled "the most dramatic decline in freedoms" of any country globally in the past decade.

Finally, the comparative analysis of the two cases brings up the following question: are bureaucratic efficiency and meritocracy mutually exclusive goals, or can they be pursued and achieved simultaneously? Based on the divergent results of Brazil and Turkey's public administration reforms since the 1980s, the temptation would be to opt for the initial assessment. However, this is not corroborated by other cases: some of the world's most efficient bureaucracies also happen to be the most meritocratic ones, such as Singapore and New Zealand. Likewise, the emphasis of the EU-backed reforms in Turkey was on improving both efficiency and meritocracy in the public administration. 
That said, it is also undeniable that promoters of traditional bureaucratic or managerial approaches have often championed a particular set of goals to the point of undermining other crucial aspects of public administration. Within the Anglo-Americanled liberal international paradigm, the nearly singular focus on efficiency and costreduction in the public sector has often led to the weakening of not only meritocracy, but also democratic accountability as a whole. This is especially the case in developing countries where democratic institutions and processes were fragile and exposed to being captured to begin with (RIZVI, 2007, p. 78). In this sense, the evolution of the Turkish civil service within the wider framework of the country's "exit from democracy" (ÖKTEM \& AKKOYUNLU, 2016) serves as a cautionary tale for Brazil.

\section{References}

AKDENIZ, I. (2016). Kamu Görevlileri Etik Kurulunu Yeniden Düşünmek [Rethinking the Council of Ethics for Public Officials]. Sayıştay Dergisi, 103. October - December, pp. 59 - 83.

AKKOYUNLU, K.; \& ÖKTEM, K. (2016). Existential insecurity and the making of a weak authoritarian regime in Turkey. Southeast European and Black Sea Studies, 16 (4), pp. $505-527$.

Bresser PereiRA, L. C. (1998). Da administração pública burocrática à gerencial. In Bresser-Pereira; Luiz Carlos; Spin, Peter (Eds). Reforma do Estado e Administração Pública Gerencial. Rio de Janeiro: Fundação Getúlio Vargas.

Cavalcante, P.; \& CaRvalho, P. (2017). The professionalization of Brazilian federal bureaucracy (1995-2014): advances and dilemmas. Revista do Administração Pública. 51(1), Rio de Janeiro, Jan/Feb.

CAVAlcANTE, P. (2018). Innovations in the federal government during the post-New Public Management Era. RAC. Revista de Administração Contemporânea, v. 22, pp. 885-902.

CORRÊA, I. M. (2016). Unveiled to regulate: The logics and trajectories of regulatory transparency policies. Unpublished PhD Thesis. London School of Economics.

CNM. (2012). Cai o número de centrais sindicais reconhecidas pelo governo. Confederação Nacional dos Metalúrgicos, 10 October.

Dahlstrom, C.; Teorell, J.; Dahlberg, S.; Hartmann, F.; Lindberg, A.; \& Nistotskaya, M. (2015). The qog expert survey dataset. University of Gothenburg: The Quality of Government Institute. 
DALhuisen, J. (2017). In Turkey, defending human rights is a crime. Politico. 19 July.

ERDıNç, I. (2014). AKP Döneminde Sendikal Alanın Yeniden Yapılanması ve Kutuplaşma: Hak-iş ve Ötekiler [Restructuring the field of trade unions and polarisation: Hak-Is and others]. Çalışma ve Toplum. Vol. 2, pp. 155-174.

EUROPEAN COMmission. (2004). Regular Report on Turkey's progress towards accession. Brussels, 6 October.

European Commission. (2005). Turkey 2005 Progress Report. Brussels, 9 November.

European Commission. (2016). Turkey 2016 Progress Report. Brussels, 9 November.

EURopeAn Commission. (2018). Turkey 2018 Report. Strasbourg, 17 April.

GAETANI, F. (2008). Constitutional public management reforms in modern Brazil 1930-1998. Unpublished PhD thesis. London School of Economics.

Freedom House. (2018). Freedom in the World 2018, https://freedomhouse.org/report/freedomworld/freedom-world-2018

GRINDLE, M. (2010). Constructing, deconstructing, and reconstructing career civil service systems in Latin America. Faculty Research Working Paper Series. Harvard Kennedy School. June.

GülER, B. A. (2010). 657'yi Değiştirmek: 9 Haziran 2010 Tasarısı Üzerine [To Change 657: About the 9 June 2010 Proposal]. Ankara University, Faculty of Political Science, 3 July.

HABERLER. (2014). Torpilliler Bir Gün Sözleşmeli Çalışıp Devlet Memuru Olmuş [Privileged employees made civil servants after a single day under contract], 9 December.

MANEO, A.; \& AMÂNCIO, T. (2015). Com metade da população, negros são só $18 \%$ em cargos de destaque no Brasil. Folha de S. Paulo, 8 June.

Nunberg, B.; \& PACHeCO, R. S. (2016) . Public management incongruity in $21^{\text {st }}$ Century Brazil. In SCHNEIDER, Ben Ross (Ed). New Order and Progress: Development and Democracy in Brazil. Oxford: Oxford University Press.

OECD. (2009). OECD Reviews of human resource management in government - Brazil. 10 December.

OECD. (2012). Human resources management country profiles, Brazil. December.

OECD. (2017). Pension reform in Brazil. Policy Memo. April.

OLIVEIRA, J. A. (2017). Puppim de. Brazilian public administration: Shaping and being shaped by governance and development. Chinese Political Science Review, Vol 2, pp. $7-21$.

OSBORNE, D.; \& GAEBLER, T. (1993). Reinventing government: How the entrepreneurial spirit is transforming the public sector. New York: Penguin.

OtA, L. A.; Fernandes, A. (2017). Servidor público ganha $67 \%$ a mais que o privado no Brasil, diz Banco Mundial. O Estado do São Paulo, 21 November. 
ÖMÜRGÖNÜLŞEN, U. (2009). The Four System Studies: Legal and Institutional Infrastructure of Ethical Administration in Turkey. Report for the Council of Europe. Ethics for the Prevention of Corruption in Turkey (TYEC). CoE Project No. EC/1062.

ÖKTEM, K.; \& AKKOYUnLU, K. (2016). Exit from democracy: Illiberal governance in Turkey and beyond. Southeast European and Black Sea Studies, 16 (4), pp. $469-480$.

PHILLIPS, D. (2016). Brazil senate approves austerity package to freeze social spending for 20 years. The Guardian. 13 December.

PichleR, W. A.; \& Menegotto, G. (2015). Union membership and industrial action in Brazilian public sector in the 2000s. Paper presented at GT-17 Reestructuración Productiva, Trabajo y Dominación Social, Congreso ALAS 2015, Costa Rica.

Republic Of TURKey.(2018). State Personnel Presidency: http://www.dpb.gov.tr/tr-tr.

RIzVI, G. (2007). Reinventing government: Putting democracy and social justice back into the discourse. In The Department of Economic and Social Affairs of the United Nations Secretariat (DESA). Public Administration and Democratic Governance: Governments Serving Citizens. Vienna, Austria.

Romero, S. (2013). Brazil, where a judge made $\$ 361,500$ in a month, Fumes over pay. New York Times, 10 February.

SOMER, M. (2016). Conquering versus democratizing the state: Political Islamists and fourth wave democratization in Turkey and Tunisia. Democratization, 24 (6), pp. 1025 - 1043.

Sото, A. (2016). Brazil's Temer unveils pension reform, sets retirement age at 65 . Reuters, 5 December.

SoYAltIN, D. (2017) Europeanization, Good Governance and Corruption in the Public Sector: The Case of Turkey. London: Routledge.

TODAIE. (1991). Kamu Yönetimi Araştırması Genel Rapor [General Report of the Public Administration Research]. Türkiye ve Orta Doğu Amme Idaresi Enstitüsü. TODAIE Yayınları.

VAN DE WALLE, S. (2006). The state of the world's bureaucracies. Journal of Comparative Policy Analysis: Research and Practice, 8 (4), pp. 437 - 448, 2006.

Velarde, J. C. C.; LAfuente, M.; \& SAnginés, M. (2014) . Al servicio del ciudadano: Una década de reformas del servicio civil en América Latina (2004-13). Banco Interamericano de Desarrollo, Washington, DC.

VOLPE, A. P. S.; \& DIAS SILVA, T. (2016). Reserva de vagas para negros na administração pública: Relatório de Pesquisa. Instituto de Pesquisa Econômica Aplicada (IPEA), Brasilia.

WORLD BANK. (2017). Um ajuste justo: Análise da eficiência e equidade do gasto público no Brasil. Revisão das Despesas Públicas, November.

WORLD BANK. (2017). Doing Business Rankings. June, http://www.doingbusiness.org/rankings 
WEF. (2018). The Global Competitiveness Report 2017-2018. World Economic Forum, https:// www.weforum.org/reports/the-global-competitiveness-report-2017-2018

YABANCI, B. (2016). Populism as the problem child of democracy: The AKP's enduring appeal and the use of meso-level actors. Journal of Southeast European and Black Sea Studies, 16 (4), p. 591 $-617$.

YENI ÇAĞ. (2016). Devlet KPSS'siz memur alacak [State to hire civil servants without central exam]. 15 August.

\section{Karabekir Akkoyunlu}

(iD https://orcid.org/0000-0002-2306-8732

Lecturer, Escola de Relações Internacionais, Fundação Getúlio Vargas (FGV). Research Associate, Centre for Southeast European Studies, University of Graz, Austria.

E-mail: karabekir.akkoyunlu@fgv.br 